\title{
Papular Eruptions in Adult Females
}

\author{
Leandro Noriega Danielle Claudino Costa Gilmayara Alves Pereira \\ Marina Lino Vieira Nilton Di Chiacchio Letícia Arsie Contin \\ Dermatology Clinic, Hospital do Servidor Público Municipal de São Paulo, São Paulo, Brazil
}

\section{Question}

\section{Case 1}

A 41-year-old Caucasian female with hypothyroidism presented to our department with multiple lesions that abruptly appeared on her forearm 2 years prior to her consultation. She reported that the lesions were stable; however, over time, new lesions occasionally emerged in the same area. She reported mild pruritus but denied previous inflammatory conditions on the site or lesions at other locations. She had been receiving regular treatment for hypothyroidism and denied any family history of it. Her dermatologic examination showed multiple small, shiny, slightly brownish erythematous papules, with some of them in the anterior and medial regions of the forearms (fig. 1a, b). Histopathologic examination confirmed the diagnosis (fig. 1c, d).
Fig. 1. Multiple small, shiny, slightly brownish erythematous papules in the anterior and medial regions of the forearms. a Right forearm. b Left forearm. c Histopathologic examination revealed multiple small ducts lined by two layers of flattened epithelial cells within dense fibrous stroma in the dermis. One duct dilated by accumulation of eosinophilic secretion is observed ( $\mathrm{H} \& \mathrm{E}$. $\times 20$ ). d Comma-like tail morphology, giving the appearance of tadpole is noted at higher magnifications (H\&E. $\times 40)$.
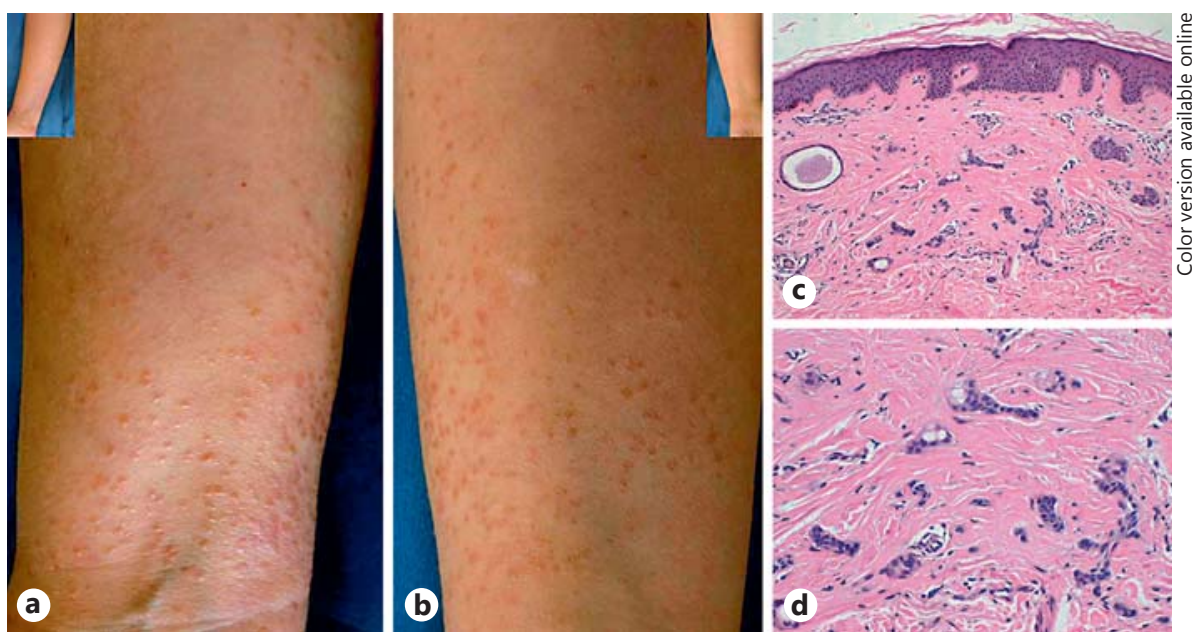

\section{KARGER}

E-Mail karger@karger.com www.karger.com/sad
(C) 2016 S. Karger AG, Base

2296-9195/16/0022-0014\$39.50/0
Leandro Noriega

Dermatology Clinic

Hospital do Servidor Público Municipal de São Paulo

60 Castro Alves, São Paulo, SP 01532000 (Brazil)

E-Mail leandronorieg@gmail.com 
Case 2

A 55-year-old, phototype III female reported the sudden appearance of multiple lesions in her cervical region 6 months previously. She denied local symptoms, triggering factors, improvement or worsening factors, and previous treatments. She also denied comorbidities or the use of continuous medications. Her dermatologic examination revealed multiple small, shiny brownish erythematous papules with a smooth surface in the anterior cervical and presternal regions (fig. 2). A histopathologic examination confirmed the same diagnosis as that observed in case 1.
Fig. 2. a, b Multiple small, shiny brownish erythematous papules in the anterior cervical and presternal regions.
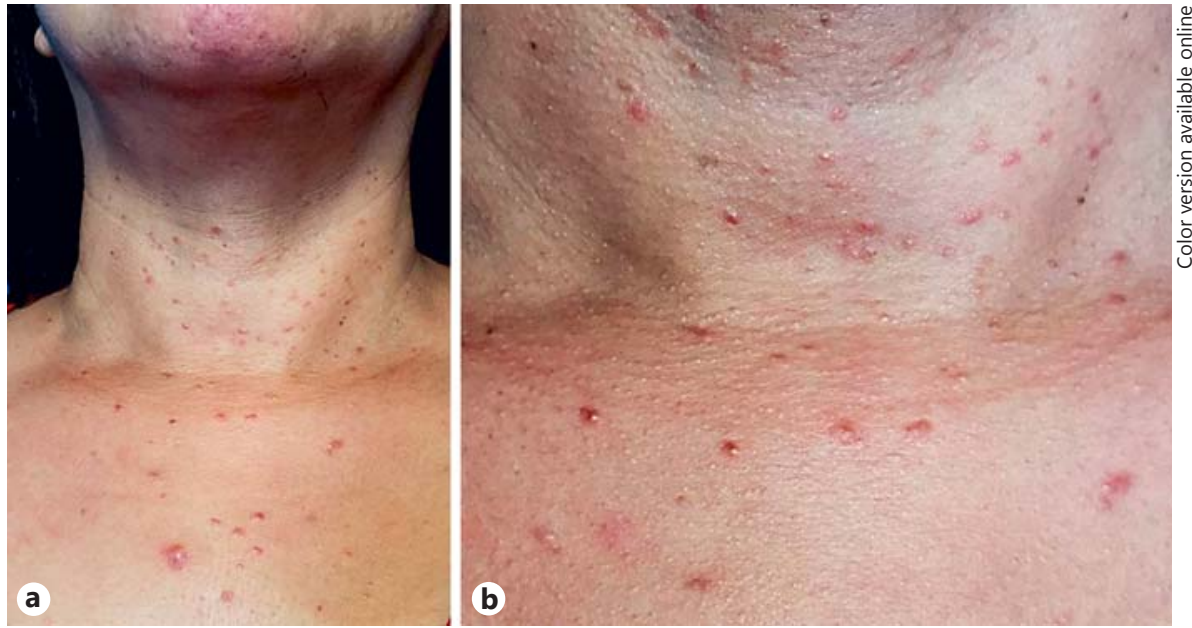


\section{Answer}

\section{Eruptive Syringoma}

First described by Kaposi [1], syringoma is a benign adnexal neoplasm, which originates from the ducts of the eccrine sweat glands $[2,3]$. It affects $0.6 \%$ of the population and can be classified as localized, generalized, familial, or associated with Down syndrome $[2,4,5]$. The localized form is the most prevalent, often sporadic, and is characterized by periocular lesions $[2,6,7]$.

Eruptive syringoma is a rare variant manifesting as a papular eruption with diverse distribution and successive crops, which is classified within the group of generalized forms $[2,4,8,9]$. Since the initial description in 1887 by Jacquet and Darier [8], about 94 cases have been reported until 2013 [10], and about 103 cases to date. Eruptive syringoma is characterized by a higher incidence in females and may affect any age group; however, $33-50 \%$ of the cases are under the age of 15 [4]. Along with these epidemiological variables, the high expression of progesterone receptors observed on immunohistochemistry suggests hormonal involvement in the pathogenesis of this disease $[11,12]$. In addition, eruptions occurring after a localized inflammatory condition such as contact dermatitis have been reported [6, 13]. As per Guitart et al. [11], these conditions specifically do not constitute a true adnexal neoplasm but rather a hyperplastic reaction in the eccrine duct. For such conditions, they propose the term 'syringomatous dermatitis'.

The eruptive form usually manifests with multiple 3-to-5-mm monomorphic papules that are shiny, firm, and range in color between skin-colored or slightly yellowish to brownish $[3,4,9,13]$. Typically, they are asymptomatic, although there may be pruritus during early phases or disease progression $[4,11]$. The most commonly affected areas are the neck, anterior thoracic region, axillae, shoulders, abdomen, and pubic region, with the lesions usually distributed symmetrically $[3,4,9]$. It may occasionally affect the forearms, hands, forehead, scalp, inguinal region, and genital region $[4,6,11]$. Differential diagnoses include the following: lichen planus, lichen nitidus, flat warts, pseudoxanthoma elasticum, Darier disease, eruptive xanthomas, eruptive vellus hair cysts, disseminated granuloma annulare, hyperplasia of the sebaceous glands, and milia $[3,4,6,13]$. Although infrequent, some familial cases of eruptive syringoma have been reported $[4,7]$. Rarely, it may compose the Nicolau-Balus syndrome, which also manifests with milia and atrophodermia vermiculata $[4,14]$.
Overall, the diagnosis is suggested by the clinical history and dermatologic examination findings, but a histopathologic analysis is needed for confirmation [4]. Histopathology shows a well-defined lesion in the dermis, with multiple small ducts lined by two layers of flattened epithelial cells within a dense fibrous stroma. Some of the ducts may assume a comma-like tail morphology, resembling the appearance of a tadpole. Furthermore, dilated ducts due to accumulation of eosinophilic secretion may be seen $[3,4,6,11]$. The different forms of presentation are indistinguishable histologically; therefore, clinical correlation is required in order to determine the classification $[4,7,9]$.

Treatment is usually specified for esthetic reasons, as the lesions tend to be stable without any significant pathological repercussions in the long term $[3,7,9]$. Rarely, spontaneous resolution may occur $[4,9]$. The response to therapy is often unsatisfactory, independent of the modality. In addition, there should be a balance between the risk of iatrogenic scar and that of recurrence of the lesion. The treatment options include cryotherapy, electrodessication, $\mathrm{CO}_{2}$ laser, surgical excision, dermabrasion, topical or systemic retinoid, topical atropine, and application of trichloroacetic acid $[3,4,13]$. Some cases showed positive response to the oral use of N-(3,4-dimethoxycinnamoyl)anthranilic acid, also known as tranilast [15].

Eruptive syringoma should be integrated within the differential diagnosis of dermatoses manifesting with papular eruption, independent of the topography of lesions and the patient's age group [4, 7].

\section{Statement of Ethics}

The authors have no ethical conflicts to disclose.

\section{Disclosure Statement}

The authors have no conflicts of interest to disclose.

\section{Key Words}

Papules - Sweat gland tumor - Eruptive syringoma
Noriega/Costa/Alves Pereira/Vieira/ Di Chiacchio/Contin 


\section{References}

1 Kaposi M: Lymphangioma tuberosum multiplex; in Fagge CH (translation ed): Hebra on Diseases of the Skin, vol. 3. London, New Sydenham Society, 1872, pp 386.

2 Patrizi A, Neri I, Marzaduri S, Varotti E, Passarini B: Syringoma: a review of twenty-nine cases. Acta Derm Venereol 1998;78:460-462.

3 Singh S, Tewari R, Gupta S: An unusual case of generalised eruptive syringoma in an adult male. Med J Armed Forces India 2014;70: 389-391.

4 Soler-Carrillo J, Estrach T, Mascaró JM: Eruptive syringoma: 27 new cases and review of the literature. J Eur Acad Dermatol Venereol 2001;15:242-246.

5 Friedman SJ, Butler DF: Syringoma presenting as milia. J Am Acad Dermatol 1987;16: 310-314.

6 Sakiyama M, Maeda M, Fujimoto N, Satoh T: Eruptive syringoma localized in intertrigi- nous areas. J Dtsch Dermatol Ges 2014;12: 72-73.

7 Resende C, Araújo C, Santos R, Pereira T, Brito $\mathrm{C}$ : Late-onset of eruptive syringomas: a diagnostic challenge. An Bras Dermatol 2015; 90(suppl 1):239-241.

8 Jacquet L, Darier J: Hidradénomes éruptifs, épithéliomes adénoïdes des glandes sudoripares ou adénomes sudoripares. Ann Dermatol Venereol 1887;8:317-323.

9 Tsunemi Y, Ihn H, Saeki H, Tamaki K: Generalized eruptive syringoma. Pediatr Dermatol 2005;22:492-493.

10 Williams K, Shinkai K: Evaluation and management of the patient with multiple syringomas: a systematic review of the literature. J Am Acad Dermatol 2016; pii: S01909622(15)02526-8.

11 Guitart J, Rosenbaum MM, Requena L: 'Eruptive syringoma': a misnomer for a reactive ec- crine gland ductal proliferation? J Cutan Pathol 2003;30:202-205.

12 Wallace ML, Smoller BR: Progesterone receptor positivity supports hormonal control of syringomas. J Cutan Pathol 1995;22:442445.

13 Avhad G, Ghuge P, Jerajani HR: Generalized eruptive syringoma. Indian J Dermatol 2015; 60:214.

14 Dupré A, Carrère S, Bonafé JL, Christol B, Lassère J, Touron P: Eruptive generalized syringomas, milium and atrophoderma vermiculata. Nicolau and Balus' syndrome (in French). Dermatologica 1981;162:281-286.

15 Horie K, Shinkuma S, Fujita Y, Ujiie H, Aoyagi S, Shimizu H: Efficacy of N-(3,4dimethoxycinnamoyl)-anthranilic acid (tranilast) against eruptive syringoma: report of two cases and review of published work. J Dermatol 2012;39:1044-1046. 